\title{
Hubungan antara regulasi emosi dan penyesuaian diri dengan stres perawat yang bertugas di ruang isolasi pasien Covid-19
}

\author{
Widya Riyania,1, Faridah Ainur Rohmah',2* \\ a,bFakultas Psikologi, Universitas Ahmad Dahlan, Yogyakarta \\ ${ }^{1}$ widya.riyani08@gmail.com; *2faridahainur@yahoo.com \\ *Correspondent Author
}

Received: 30-03-2021

Revised: 14-06-2021

Accepted: 24-07-2021

KATAKUNCI

penyesuaian diri; regulasi emosi; stres

\section{KEYWORDS}

emotion regulation; self-adjustment; stress
ABSTRAK

Tingginya angka pasien Covid-19 saat ini turut berdampak pada kelelahan perawat, khususnya perawat yang langsung bersentuhan dengan pasien Covid di ruang islosasi. Oleh karena itu, penting untuk mengetahui faktor yang memiliki hubungan dengan tinggi rendahnya tingkat stres perawat yang menangani secara langsung pasien Covid19 di rumah sakit. Penelitian ini bertujuan untuk mengetahui hubungan antara regulasi emosi dan penyesuaian diri dengan stres perawat yang bertugas di ruang isolasi pasien Covid-19. Metode yang digunakan adalah kuantitatif dengan pendekatan korelasi. Subjek penelitian yaitu 70 perawat diruang isolasi Rumah Sakit Umum Daerah Praya. Metode penelitian ini menggunakan pendekatan kuantitatif dengan desain korelasi. Alat pengumpulan data yang digunakan adalah skala stres, skala regulasi emosi, dan skala penyesuaian diri. Teknik analisis data yang digunakan adalah analisis regresi berganda dengan bantuan program SPSS 16.0 for windows. Berdasarkan hasil analisis regresi menunjukan $\mathrm{R}=0,442$ dengan $\mathrm{p}=0,001(\mathrm{p}<0,01)$ yang berarti ada hubungan yang sangat signifikan antara regulasi emosi dan penyesuaian diri dengan stres perawat yang bertugas di ruang isolasi. Hasil uji korelasi product moment Pearson antara regulasi emosi dengan stres menghasilkan nilai $r x y=-$ 0,358 dan $p=0,023(p<0,05)$. Hasil uji korelasi antara penyesuaian diri dengan stres menghasilkan nilai $r x y=-0,333$ dan $p=0,48(p<0,05)$. Hasil penelitian ini menyimpulkan bahwa hubungan negatif antara regulasi emosi dengan stres. Semakin tinggi regulasi emosi maka semakin rendah stres sebaliknya semakin rendah regulasi emosi maka akan semakin tinggi stres. Selain itu ada hubungan negatif antara penyesuaian diri dengan stres. Semakin tinggi penyesuaian diri maka semakin rendah stres sebaliknya semakin rendah penyesuaian diri maka akan semakin tinggi stres.

The relationship between emotion regulation and adjustment to stress of nurses on duty in isolation rooms for covid-19 patients

The current high number of Covid-19 patients also has an impact on nurses' fatigue, especially nurses who directly come into contact with Covid patients in the isolation room. Therefore, it is important to know the factors that have a relationship with the high and low stress levels of nurses who directly handle Covid-19 patients in hospitals. This study aims to determine the relationship between emotional regulation and adjustment to the stress of nurses on duty in the isolation room for 
Covid-19 patients. The method used is quantitative with a correlation approach. The research subjects were 70 nurses in the isolation room of the Praya Regional General Hospital. This research method uses a quantitative approach with a correlation design. Data collection tools used are stress scale, emotion regulation scale, and adjustment scale. The data analysis technique used is multiple regression analysis with the help of SPSS 16.0 for windows. Based on the results of the regression analysis showed $R=0.442$ with $p=0.001$ ( $p<0.01$ ) which means that there is a very significant relationship between emotional regulation and adjustment to the stress of nurses on duty in the isolation room. The results of the Pearson product moment correlation test between emotion regulation and stress resulted in a value of rxy=-0.358 and $p=0.023(p<0.05)$. The results of the correlation test between adjustment and stress resulted in a value of rxy=-0.333 and $p=0.48$ $(p<0.05)$. The results of this study conclude that there is a negative relationship between emotion regulation and stress. The higher the emotional regulation, the lower the stress, the lower the emotional regulation, the higher the stress. In addition, there is a negative relationship between self-adjustment and stress. The higher the adjustment, the lower the stress, the lower the adjustment, the higher the stress.

This is an open-access article under the CC-BY-SA license.

\section{Pendahuluan}

Menurut World Health Organization (WHO, 2020) Coronavirus adalah suatu kelompok virus yang dapat meyebabkan penyakit pada hewan atau manusia. Beberapa jenis Coronavirus diketahui menyebabkan infeksi saluran pernafasan pada manusia, mulai dari batuk, pilek hingga yang lebih serius seperti Middle East Respiratory Syndrome (MERS) dan Severe Acute Respiratory Syndrome (SARS), dan pada saat ini ditemukan virus jenis baru yaitu Coronavirus yang menyebabkan penyakit Covid-19. World Health Organization (WHO) menyatakan Covid-19 adalah penyakit menular yang disebabkan oleh jenis Coronavirus yang baru ditemukan. Virus ini merupakan virus dan penyakit baru yang sebelumnya tidak dikenal sebelum terjadi wabah di Wuhan, Tiongkok, pada bulan Desember 2019 (WHO, 2020).

Dilansir dari Detiknews (2020), Presiden Joko Widodo mengumumkan pada tanggal 2 Maret 2020 bahwa ada dua orang Indonesia yang terjangkit virus Corona yang diduga berawal dari pertemuan yang dilakukannya dengan warga Negara Jepang, yakni perempuan berusia 31 tahun dan ibu berusia 64 tahun. Akan tetapi tim pakar Fakultas Kesehatan Masyarakat Universitas Indonesia (FKM UI) memprediksi virus Corona telah masuk ke Indonesia sejak minggu ke 3 Januari 2020. Berdasarkan hasil laporan Orang Dalam Pantauan (ODP) di salah satu daerah sehingga dinilai sebagai bukti telah terjadi penularan Corona secara lokal.

Covid-19 merupakan jenis penyakit yang patut diwaspadai karena penularannya melalui manusia ke manusia dan terjadi sangat cepat. Setiap harinya orang yang terkena virus Covid19 semakin bertambah. Data Statistik Dinas Kesehatan NTB pada tanggal 19 Januari 2021 menyebutkan kasus positif Covid-19 di Indonesia sebanyak 927.380 orang, jumlah yang dirawat 146.182 orang, jumlah yang sembuh sebanyak 753.948 orang, dan meninggal sebanyak 26.590 orang. Sejauh ini, kasus Positif Covid-19 di NTB sebanyak 6700 orang, jumlah yang dirawat 1049 orang, jumlah yang sembuh sebanyak 5339 orang, dan meninggal 
sebanyak 316 orang (Dinas Kesehatan NTB, 2020).

Tenaga medis sebagai garda terdepan dalam penanganan kasus Covid-19 dan berkemungkinan untuk tertular virus sangatlah besar. Menurut Lai, Ma, Wang, Cai, Hu, Wei, ... (2020) dalam penelitiannya yang mengkaji kesehatan jiwa menunjukan dari 1.257 tenaga medis di China yang menangani pasien Covid-19, sebesar 60,8\% adalah perawat, 9,2\% dokter, dan $30 \%$ adalah tenaga medis yang berada di garda terdepan. Secara keseluruhan, penelitian ini menemukan adanya 20,29\% responden mengalami gejala depresi, $29,03 \%$ mengalami gejala cemas, $15,68 \%$ mengalami insomnia, dan 35\% mengalami stres. Dibandingkan dengan bekerja di baris kedua, bekerja di garda terdepan langsung menangani pasien Covid-19 ternyata menjadi faktor resiko untuk semua gejala psikiatri dan stres merupakan gejala yang paling banyak dialami oleh tenaga medis.

Suhaya dan Sari (2019) meneliti mengenai tingkat stres perawat dalam merawat pasien dengan penyakit menular di Rumah Sakit Umum Daerah dr. Zainoel Abidin Banda Aceh, dan hasil penelitian menunjukan $85,1 \%$ perawat mengalami stres ringan, $14,9 \%$ perawat mengalami stres sedang, serta tidak ada yang mengalami stres berat. Berdasarkan penelitian ini, dapat disimpulkan bahwa tingkat stres perawat dalam merawat pasien dengan penyakit menular di RSUDZA Banda Aceh termasuk dalam kategori ringan dan sedang. Berdasarkan semua data yang diperoleh selanjutnya dalam penelitian ini meneliti mengenai variabel stres karena stres adalah gejala yang paling banyak dialami oleh perawat yang menangani pasien dengan penyakit yang menular dan berbahaya seperti Covid-19.

Menurut Santrock (2003) stres adalah respon individu terhadap keadaan atau kejadian yang memicu stres (stressor) yang mengancam dan mengganggu kemampuan seseorang untuk menanganinya. Stres merupakan suatu kondisi dimana keadaan tubuh terganggu karena tekanan psikologis. Biasanya stres dikaitkan bukan karena penyakit fisik tetapi lebih mengenai kejiwaan (Vandestra, 2018). Menurut Robbins dan Judge (2012), stres juga dapat diartikan sebagai suatu kondisi yang menekan psikis seseorang dalam suatu kesempatan dimana untuk mencapai kesempatan tersebut terdapat batasan atau penghalang. Stres adalah bentuk ketegangan dari fisik, psikis, emosi maupun mental. Bentuk ketegangan ini mempengaruhi kinerja keseharian seseorang. Bahkan stres dapat membuat produktivitas menurun, rasa sakit, dan gangguan mental (Nugraheni, Wiyatini, \& Wiradona, 2018).

Dampak dan akibat yang ditimbulkan dari stres menurut Gitosudarmo dan Sudita (2000) yaitu, pertama subjektivitas, berupa kekhawatiran atau ketakutan, agresi, apatis, rasa bosan, depresi, keletihan, kehilangan kendali emosi, gugup, dan kesepian. Kedua perilaku, berupa luapan emosional, makan atau merokok secara berlebihan, perilaku impulsif, kecanduan alkohol dan penyalahgunaan obat. Ketiga kognitif, berupa ketidakmampuan untuk membuat keputusan yang masuk akal, kurang perhatian, sangat sensitif terhadap kritik, daya konsentrasi rendah, dan hambatan mental. Keempat fisiologis, berupa kandungan glukosa darah meningkat, denyut jantung dan tekanan darah meningkat, mulut kering, bola mata melebar, dan panas dingin. Kelima organisasi, yaitu mengenai absensi, produktivitas rendah, terasing, komitmen dan loyalitas berkurang. Secara spesifik dampak stres berpengaruh terhadap pekerjaan terutama menurunkan motivasi bekerja (Anggraini \& Nanda, 2021).

Hardjana (1994) mengungkapkan bahwa stres merupakan keadaan atau kondisi yang diciptakan. Hal yang dianggap menyebabkan munculnya stres dan membuat individu mengalami stres adalah melihat ketidaksesuaian antara realita, keadaan, sumber daya biologis, psikologis, dan sosial. Hal tersebut membutuhkan kemampuan individu untuk dapat mengatur emosi. Kondisi inilah yang umumnya disebut dengan regulasi emosi. Regulasi emosi adalah suatu cara untuk mengatur emosi yang dimiliki individu dan bagaimana mengekspresikan emosi yang dirasakan (Gross, 1999). Namun, untuk mengatur emosi dengan baik maka diperlukan suatu strategi yang dapat diterapkan untuk menghadapi situasi emosional, dimana hal tersebut dapat dilakukan dengan cara meregulasi emosi dengan baik. Hal tersebut sangat berguna bagi perawat yang bertugas menangani pasien Covid-19 (Gross, 1999). 
Sejauh ini, bukan hanya regulasi emosi saja yang dibutuhkan dalam menanggulani stress, akan tetapi penyesuaian dengan keadaan dan situasi yang baru juga harus dapat dilakukan oleh perawat, seperti menyesuaikan diri dengan rekan kerja yang baru, menggunakan alat pelindung diri (APD) yang sebelumnya tidak pernah digunakan, ruang kerja dan peraturan yang baru sehingga perawat dituntut juga untuk dapat menyesuaikan diri dengan perubahan situasi tersebut.

Schneiders (1964) berpendapat bahwa penyesuaian diri mempunyai banyak arti, antara lain untuk menguasai perasaan yang tidak menyenangkan atau usaha manusia untuk menguasai tekanan akibat dorongan kebutuhan, usaha memelihara keseimbangan antara pemenuhan kebutuhan dan tuntutan lingkungan, serta usaha menyelaraskan hubungan individu dengan realitas. Fenomena yang dihadapi individu yang menyebabkan perubahan dalam kehidupan mengaharuskan individu untuk menyesuaikan diri. Menyesuaikan diri juga merupakan proses dimana dimensi fisiologis atau dimensi psikologis berubah dalam merespon stresor (Taylor, Lilis, \& LeMone, 1997).

Secara empirik, penelitian serupa sudah banyak dilakukan oleh para peneliti sebelumnya tetapi dengan menggunakan sampel karyawan perusahaan, ibu dari anak ABK, penderita diabetes, mahasiswa, guru, santri, perawat kesehatan jiwa dan lansia. Namun penelitian tentang stres pada sampel tenaga kesehatan terutama pada perawat yang bertugas di ruang isolasi Covid 19 dengan variabel bebas regulasi emosi dan penyesuaian diri sejauh ini belum pernah dilakukan. Sementara, berdasarkan pemaparan sebelumnya diduga bahwa regulasi emosi dan penyesuaian diri memiliki hubungan dengan stres perawat yang bertugas di ruang isolasi pasien Covid-19. Hal tersebut pada akhirnya mendorong peneliti untuk mengkaji lebih lanjut hubungan antara regulasi emosi dan penyesuaian diri dengan stres pada perawat yang bertugas di ruang isolasi pasien Covid-19. Tujuannya adalah agar penelitian ini dapat berkontribusi bagi pengembangan ilmu psikologi, khususnya psikologi industri organisasi. Penelitian ini juga diharapkan dapat menjadi rekomendasi bagi para pengambil kebijakan dalam bidang kesehatan untuk mempertimbangkan hasil kajian dari penelitian ini ke kemudian hari tentang pentingnya regulasi emosi dan kemampuan penyesuaian diri terhadap stres yang dialami tenaga kesehatan dalam hal ini perawat.

\section{Metode}

Metode yang digunakan pada penelitian ini adalah kuantitatif dengan desain korelasi. Subjek penelitian ini adalah perawat yang bertugas di ruang isolasi pasien Covid-19 Rumah Sakit Umum Daerah (RSUD) Praya yang berjumlah 70 orang, karena jumlah subjeknya kurang dari 100 orang, maka peneliti mengambil 100\% dari jumlah populasi yang ada, dengan demikian dalam penelitian ini teknik yang digunakan adalah teknik sensus (studi populasi) tanpa harus menarik sampel dan menggunakan seluruh populasi (Sugiyono, 2017). Penelitian ini menggunakan tiga skala yaitu skala stres dengan koefisien reliabilitas 0,879 , skala regulasi emosi dengan koefisien reliabilitas 0,911, dan skala penyesuaian diri dengan koefisien reliabilitas 0,906 .

Data pada penelitian ini diambil pada bulan Desember 2020 di Rumah Sakit Umum Daerah (RSUD) Praya. Rumah sakit ini adalah salah satu rumah sakit rujukan bagi pasien yang menderita Covid-19. Penelitian ini dilakukan dengan menyebarkan skala yang dititipkan kepada kepala bidang keperawatan Rumah Sakit Umum Daerah Praya yang kemudian skala tersebut dibagikan kepada 70 perawat yang bertugas di ruang isolasi. Setelah data terkumpul, data tersebut kemudian dianalisis menggunakan analisis regresi linear berganda. Sebelum melakukan uji hipotesis, dilakukan uji prasyarat berupa uji normalitas, uji linearitas, dan uji multikolinearitas. Keseluruhan data akan diolah menggunakan komputasi data, pada penelitian ini menggunakan bantuan aplikasi Statistiical Product and Service Sollution (SPSS) versi 16.0 for windows. 


\section{Hasil}

Hasil analisis regresi berganda pada tabel 1 menunjukan koefisien regresi dari regulasi emosi dan penyesuaian diri dengan stres perawat adalah sebesar $R=0,442$ dengan $p=0,001$ $(p<0,01)$. Hasil analisis tersebut menunjukkan bahwa hipotesis bahwa ada hubungan yang sangat signifikan antara regulasi emosi dan penyesuaian diri dengan stres perawat yang bertugas di ruang isolasi pasien Covid-19 Rumah Sakit Umum Daerah Praya.

Tabel 1.

Hasil Analisis Regresi Berganda

\begin{tabular}{llll}
\hline Variabel & $\boldsymbol{R}$ & Sig. $(\boldsymbol{p})$ & Keterangan \\
\hline Regulasi emosi dan penyesuaian diri ${ }^{*}$ stres & 0,442 & 0,001 & Sangat Signifikan \\
\hline
\end{tabular}

Hasil uji korelasi product moment Pearson pada tabel 2 menunjukan koefisien korelasi antara variabel regulasi emosi dengan stres diperoleh $r x y=-0,358$ dengan $p=0,023(p<0,05)$. Hasil analisis tersebut menunjukkan bahwa terdapat hubungan negatif yang signifikan antara regulasi emosi dengan dengan stres perawat yang bertugas di ruang isolasi pasien Covid-19 di Rumah Sakit Umum Daerah Praya. Artinya semakin tinggi regulasi emosi yang dimiliki, maka semakin rendah tingkat stres perawat. Begitu pula sebaliknya semakin rendah regulasi emosi yang dimiliki, maka akan semakin tinggi tingkat stres perawat.

Hasil uji korelasi product moment Pearson selanjutnya pada tabel 2 juga menunjukan koefisien korelasi antara variabel variabel penyesuaian diri dengan stres diperoleh rxy=0,333 dengan $\mathrm{p}=0,048(\mathrm{p}<0,05)$. Hasil analisis tersebut menunjukkan bahwa terdapat hubungan negatif yang signifikan antara penyesuaian diri dengan stres perawat yang bertugas di ruang isolasi pasien Covid-19 di Rumah Sakit Umum Daerah Praya. Artinya semakin tinggi kemampuan perawat dalam menyesuaikan diri maka semakin rendah tingkat stres yang dialami. Begitu pula sebaliknya, semakin rendah kemampuan perawat menyesuaikan diri, maka semakin tinggi tingkat stres yang dialami.

Tabel 2.

Hasil Analisis Korelasi Product Moment Pearson

\begin{tabular}{llll}
\hline Variabel & $\boldsymbol{r x y}$ & Sig. $(\boldsymbol{p})$ & Keterangan \\
\hline Regulasi emosi ${ }^{*}$ stress & $-0,358$ & 0,023 & Hipotesis diterima \\
Penyesuaian diri ${ }^{*}$ stress & $-0,333$ & 0,048 & Hipotesis diterima \\
\hline
\end{tabular}

\section{Pembahasan}

Berdasarkan hasil analisis regresi yang telah dilakukan untuk menguji hubungan antar variabel pada penelitian ini menunjukan bahwa ada hubungan antara regulasi emosi dan peyesuaian diri dengan stres perawat yang bertugas di ruang isolasi pasien Covid-19 di Rumah Sakit. Hal tersebut memperkuat teori yang dikemukakan oleh Santrock (2003) mengenai faktor-faktor yang mempengaruhi stres yang pertama adalah faktor lingkungan yaitu interaksi individu dengan lingkungannya berhubungan erat dengan kesehatan individu. Kejadian sehari-hari seperti tugas yang berlebihan, tuntutan pekerjaan, frustrasi, dan keadaan lingkungan yang tidak menyenangkan juga dapat mengakibatkan stres. Penyesuaian diri merupakan suatu proses individu dalam memberikan respon terhadap tuntutan lingkungan dan kemampuan melakukan koping terhadap stres (Nevid, Rathus, \& Green, 2005). Kedua adalah faktor kepribadian yaitu sekelompok karakteristik yang ada dalam individu menjadi penyebab munculnya stres. Kepribadian yang memiliki rasa kompetitif yang berlebihan, kemauan yang keras, tidak sabar, dan mudah marah akan menimbulkan reaksi stres yang lebih dibandingkan dengan individu yang dapat mengontrol emosinya. Oleh karena itu untuk mengantisipasi terjadinya stres yang berlebihan maka individu harus memiliki kemampuan penyesuaian diri yang baik. Ketiga adalah faktor kognitif, faktor 
kognitif adalah salah satu faktor yang berpengaruh terhadap regulasi emosi baik secara intrinsik maupun ekstrinsik.

Berdasarkan hasil penelitian menunjukan regulasi emosi memiliki hubungan negative yang signifikan dengan tinggi ataupun rendahnya stress yang dialami perawat. Hasil penelitian ini diperkuat dengan hasil penelitian yang dilakukan oleh Ikasari dan Kristiana (2017) bahwa ada hubungan negatif antara regulasi emosi dengan stres. Hubungan negatif menunjukkan semakin tinggi regulasi emosi individu maka stres semakin rendah, sebaliknya semakin rendah regulasi emosi maka stres akan semakin tinggi. Adapun penelitian yang dilakukan oleh Kadi, Bahar, dan Sunarjo (2020) menyatakan bahwa terdapat hubungan negatif yang signifikan antara variabel regulasi emosi dengan stres. Korelasi negatif ini menunjukkan bahwa semakin tinggi stres maka semakin rendah regulasi emosi, begitupun sebaliknya semakin tinggi regulasi emosi maka semakin rendah stres yang dialami. Berdasarkan penelitian yang dilakukan oleh Pusvitasari, Wahyuningsih, dan Astuti (2016) juga mengungakapkan bahwa pelatihan regulasi emosi memiliki pengaruh terhadap menurunnya tingkat stres kerja. Hal ini dimaksudkan agar individu dapat mewaspadai setiap perubahan emosi yang dirasakan, sehingga mampu mengambil tindakan yang tepat ketika sedang menghadapi situasi yang menekan. Kemampuan regulasi emosi menjadi penting bagi individu untuk dapat melakukan coping terhadap berbagai masalah, serta mampu menekan impuls terutama masalah di tempat kerja. Orang yang mampu mengendalikan diri atau memiliki regulasi emosi yang baik akan mampu mengelola emosi dengan baik, tetap teguh, berpikir positif, tidak goyah, dan mampu berpikir dengan jernih serta tetap fokus meski dalam tekanan maupun situasi yang terberat (Goleman, 2003).

Thompson (1994) mendefinisikan bahwa regulasi emosi sebagai proses intrinsik dan ekstrinsik yang bertanggung jawab untuk memonitor, mengevaluasi, dan memodifikasi reaksi emosi secara sungguh-sungguh dan terus-menerus untuk mencapai tujuan. Thompson (1994) menyatakan bahwa regulasi emosi dapat dilakukan dengan tiga cara yang pertama adalah kemampuan memonitor emosi (emotions monitoring) yaitu kemampuan untuk menyadari dan memahami dari keseluruhan proses yang terjadi dalam diri, pikiran dan latar belakang dari tindakan individu. Emotions monitoring sangat dibutuhkan ketika individu mengalami gejala stres baik dari gejala fisiologis, gejala psikologis, bahkan gejala perilaku karena ketika individu memiliki kemampuan dalam memahami dan sadar atas semua tindakan yang dilakukan maka kemungkinan untuk mengalami stres sangat rendah. Kemudian kemampuan mengevaluasi emosi (emotions evaluating) yaitu kemampuan untuk mengelola dan menyeimbangkan emosi-emosi yang dialami individu. Kemampuan untuk mengelola emosi negatif seperti kemarahan, kesedihan, kecewa, dendam dan benci akan membuat individu tidak terbawa dan terpengaruh secara mendalam yang dapat mengakibatkan individu tidak dapat berfikir secara rasional. Oleh karena itu, kemampuan berpikir positif sangat dibutuhkan oleh perawat, agar saat mengalami situasi yang mampu mengakibatkan stres maka dengan mudah pula perawat tersebut dapat menanganinya. Setelah itu, kemampuan memodifikasi emosi (emotions modification) yaitu kemampuan untuk mengubah emosi sehingga mampu memotivasi diri terutama ketika individu berada dalam putus asa, cemas dan marah. Kemampuan ini membuat individu mampu bertahan dalam menghadapi stresor yang baru, seperti harus mampu mengelola emosi ketika menghadapi pasien, rekan kerja, bahkan situasi yang ada dalam ruang isolasi sehingga individu tersebut tidak mengalami stres.

Faktor lain yang mempengaruhi stres berdasarkan hasil penelitian ditunjukan dengan adanya hubungan antara penyesuaian diri dengan stress yang dialami perawat. Hasil penelitian ini sesuai dengan pendapat Nevid, dkk (2005) yang menjelaskan bahwa salah satu faktor yang mempengaruhi stress adalah penyesuaian diri. Menurut Schneider (1964) penyesuaian diri adalah usaha manusia untuk menguasai perasaan tidak menyenangkan dan menguasai tekanan akibat dorongan kebutuhan, usaha memelihara keseimbangan antara 
pemenuhan kebutuhan dan tuntutan lingkungan, serta usaha menyelaraskan hubungan individu dengan realitas. Sementara itu, aspek penyesuaian diri menurut Schneiders (1964) adalah adaptation adalah usaha memelihara keseimbangan antara kebutuhan dan tuntutan ligkungan. Hal tersebut mengharuskan individu untuk dapat memenuhi tuntutan baru seperti menyesuaikan diri dengan rekan kerja yang baru, ruang kerja baru, aktivitas dan tugas yang baru sehingga aspek adaptation sangat dibutuhkan agar individu tidak mudah stres dan dapat menjalani tugas dengan baik. Conformity adalah suatu bentuk pengaruh sosial dengan cara individu mengubah sikap dan tingkah laku agar sesuai dengan norma sosial yang ada. Akibatnya individu yang bertugas di ruang isolasi harus mengikuti dan mematuhi aturan yang baru dalam penanganan pasien Covid-19 agar sesuai dengan norma yang ada dan terhindar dari stresor yang dapat mengakibatkan stres. Kemudian aspek mastery dimana individu dituntut untuk dapat membuat rencana dan mengorganisasikan suatu respon sehingga dapat menyusun dan menanggapi masalah dengan efisien dan menghasilkan penyesuaian diri yang baik agar terhindar dari gejala stres. Selain itu, dalam menghadapi gejala-gejala stres yang timbul setiap individu juga memiliki cara dan respon masing-masing dalam menanggapi masalah hal tersebut dinamakan individual variation.

Kondisi lingkungan juga merupakan faktor yang penting dalam melakukan proses penyesuaian diri. Apabila perawat mampu menyesuaikan diri dengan lingkungannya berarti seorang perawat mampu menyelarasakan kebutuhannya dengan tuntutan lingkungannya, sehingga individu tidak akan mudah merasa stres. Penyesuaian diri merupakan suatu proses individu dalam memberikan respon terhadap tuntutan lingkungan dan kemampuan melakukan koping terhadap stres (Nevid, 2005). Dikatakan demikian, apabila individu menghadapi stres dan mampu menyesuaikan diri dengan stresor yang dihadapi. Maka kemungkinan individu tersebut memiliki tingkat stres yang rendah. Hal tersebut sesuai dengan penelitian yang dilakukan oleh Handono dan Bashori (2013) bahwa ada hubungan negatif yang signifikan antara penyesuaian diri dan dukungan sosial dengan stres lingkungan. Semakin tinggi penyesuaian diri dan dukungan sosial maka semakin rendah stres lingkungan dan semakin rendah penyesuaian diri dan dukungan sosial maka semakin tinggi stres lingkungan. Selain itu sejalan dengan penelitian yang dilakukan oleh Arishanti dan Juniarly (2019) bahwa penyesuaian diri memiliki peran terhadap stres dan tingkat penyesuaian diri juga dapat mempengaruhi besarnya stres yang dirasakan individu. Kondisi lingkungan selalu berubah setiap saat, oleh sebab itu individu dituntut untuk dapat membina dan menyesuaikan diri dengan bentuk-bentuk hubungan yang baru dalam berbagai situasi. Interaksi individu diluar lingkungan dengan keluarga melengkapi sumber-sumber stres, seperti di lingkungan pekerjaan.

\section{Simpulan}

Berdasarkan hasil penelitian yang telah diuraikan sebelumnya, maka dapat disimpulkan bahwa secara bersama-sama adanya hubungan yang sangat signifikan antara regulasi emosi dan penyesuaian diri dengan stres perawat yang bertugas di ruang isolasi pasien Covid-19 di Rumah Sakit. Selanjutnya ada hubungan negatif yang signifikan antara regulasi emosi dengan stres. Artinya ketika perawat memiliki regulasi emosi yang tinggi maka stres yang dialaminya rendah. Sebaliknya apabila regulsi emosi perawat rendah maka stres yang dialaminya tinggi. Adapun sumbangan efektif regulasi emosi terhadap stres sebesar 9,880\%. Terakhir, bahwa hasil penelitian menyimpulkan adanya hubungan negatif yang signifikan antara penyesuaian diri dengan stres. Artinya ketika perawat memiliki penyesuaian diri yang tinggi, maka stres yang dialami akan menjadi rendah. Sebaliknya apabila penyesuaian diri perawat rendah, maka stres yang dialami akan menjadi tinggi. Adapun sumbangan efektif penyesuaian diri terhadap stres sebesar 5,927\%. 


\section{DAFTAR PUSTAKA}

Anggraini, I. P., \& Nanda, D. P. (2021). Effects of social support toward working stress of the nurses of X hospital. STRADA Jurnal Ilmiah Kesehatan. vol. 10. No. 1,1127-1137.

Arishanti, N., \& Juniarly, A. (2019). Hardiness, penyesuaian diri dan stres pada siswa taruna. Jurnal Psikologi, Vol. 4, No.2.

Detiknews. (2020). Kapan Sebenarnya corona pertama kali masuk RI? . Online. Diunduh dari https://news.detik.com/berita/d-4991485/kapan-sebenarnya-corona-pertama-kalimasuk-ri. 21 Mei 2020.

Dinas Kesehatan NTB. (2020). Data statistik Covid-19 NTB. Online. Diunduh dari https://corona.ntbprov.go.id/. 21 Mei 2020.

Gitosudarmo \& Sudita (2000). Perilaku keorganisasian, edisi pertama. Yogyakarta: Erlangga.

Goleman, D. (2003). Emotional intelligence. Jakarta: PT Gramedia.

Gross, J. J. (1999). Emotion regulation: past, present, future. Journal Cognition and Emotion 1999, Vol. 13, No.5, 551-573.

Hadi, S. (2003). Metodologi research. Yogyakarta: Pustaka Andi.

Handono, O., \& Bashori, K. (2013). Hubungan antara penyesuaian diri dan dukungan sosial terhadap stres lingkungan pada santri baru. Empathy, vol. 1, No. 2, 79-89.

Hardjana, A. (1994). Stres tanpa distress seni mengolah stres. Yogyakarta: Kanisius.

Ikasari, A., \& Kristiana, I. (2017). Hubungan antara regulasi emosi dengan stres pengasuhan ibu yang memiliki anak cerebral palsy. Jurnal Empati, vol. 6, No. 4, 323-328.

Kadi, A. R., Bahar, H., \& Sunarjo, I. S. (2020). Hubungan antara regulasi emosi dengan stres akademik pada mahasiswa fakultas kedokteran universitas Halu Oleo. Jurnal Sublimpasi, vol. 1, No. 2.

Lai, J., Ma, S., Wang, Y., Cai, Z., Hu, J., Wei, N., \& ... (2020). Factors associated with mental health outcomes among health care workers exposed to coronavirus disease 2019.JAMA Network Open.

Nevid, J. S., Rathus, S. A., \& Greene, B. (2005). Pengantar psikologi abnormal. Bandung: Erlangga.

Nugraheni, H., Wiyatini, T., \& Wiradona, I. (2018). Kesehatan masyarakat dalam determinan sosial budaya. Yogyakarta: CV. Budi Utama.

Pusvitasari, P., Wahyuningsih, H., \& Astuti, Y. D. (2016). Efektivitas pelatihan regulasi emosi untuk menurunkan stres kerja pada anggota reskrim. Jurnal Intervensi Psikologi, vol. 8, No.1.

Robbins, S., \& Judge, T. (2012). Organizational behavior (15th ed). British Library.

Santrock, J. W. (2003). Adolescene: Perkembangan remaja. Jakarta: Erlangga.

Schneider, A. (1964). Personal adjusment and mental health. Holt: Rinehart and Winston.

Sugiyono. (2017). Metode penelitian kuantitatif, kualitatif, dan R\&D. Bandung: Alfabeta.

Suhaya, I., \& Sari, H. (2019). Tingkat stres perawat dalam merawat pasien dengan penyakit menular di Rumah Sakit Umum Daerah dr. Zainoel Abidin Banda Aceh. JIM FKEP, Vol.4, No.1.

Taylor C, Lilis C, LeMone. P. (1997). Fundamental of nursing: The art and science of nursing care. Philadelphia: Lippinoot-Raven Publishers.

Thompson, R. A. (1994). Emotion regulation: A theme in search of definition. Monographs of the Society for Research in Child Development.

Vandestra, M. (2018). Ibadah shalat tahajud sebagai terapi penyembuhan penyakit kanker dan stress. Jakarta: Dragon Promedia.

World Helath Organization (2020). Coronavirus. world health organization. Online. Diunduh dari https://www.who.int/indonesia/news/novel-coronavirus/qa-for-public. 21 Mei 2020 . 